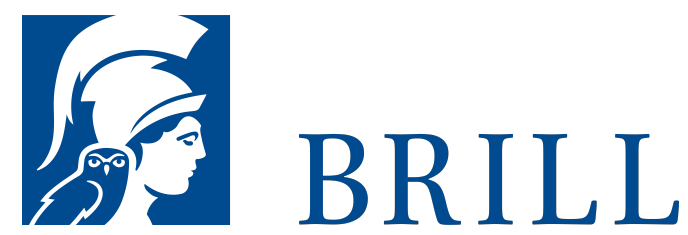

\title{
Medien und Medialität des Epischen in Literatur und Film des 20. Jahrhunderts
}

\author{
Bertolt Brecht - Uwe Johnson - Lars von Trier \\ Authors: Lothar van Laak and Lothar van Laak
}

Was ist die grundlegende Qualität unseres Erzählens in und für die Medien? Wie prägen Medien und Medialität das Erzählen und das Erzählte? Die Studie entwickelt am epischen Theater Brechts, am medial gestalteten Erzählen bei Brecht und Uwe Johnson und an der mythischen und zugleich reflektierten Filmästhetik Lars von Triers die Bestimmungen und Konzeptionen des Epischen als grundlegende historische und systematische Antwort auf diese Fragen.

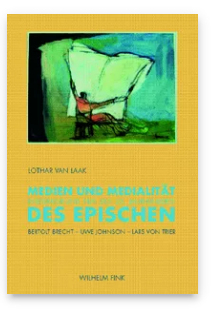

Pages: 376

Seiten

Language:

German

Publisher: Brill |

Fink

E-Book (PDF)

Released online:

16 Dec 2019

ISBN: $978-3^{-}$

8467-4811-4

List price

USD $\$ 84.00$

Paperback

Publication date:

22 Jul 2009

ISBN: $978-3^{-}$

7705-4811-8

List price

USD $\$ 84.00$ 
For more information see brill.com

Order information: Order online at brill.com +44330 333 0049 | customerservices@brill.com Submission information: brill.com/authors

Titles published by Brill | Fink, Brill | mentis or Brill | Schöningh: +49(o)715413279216| brill@brocom.de 